\title{
PENINGKATAN KEMAMPUAN MANAJERIAL KEPALA SEKOLAH MELALUI MORNING BRIEFING DI SD NEGERI 3 WIROTAMAN KEC. AMPELGADING KAB. MALANG
}

\author{
Uki Santoso \\ Kepala SD Negeri 3 Wirotaman Kec. Ampelgading Kab. Malang \\ santoso.ukiks@gmail.com
}

\begin{abstract}
Wirotaman Public Elementary School 3 Ampelgading District Malang Regency as a school where the writer is in charge for example, has 6 educators / teachers. In fact, these educators often show their lack of solidarity in dealing with various problems that arise within the school and outside the school. Based on the observation of the author, it was found that some of the problems faced by school residents were caused by misunderstandings due to lack of communication (miss communication). This can be one of the causes of less labor productivity/performance of educators and ultimately can affect student learning achievement as well. Considering these conditions, on this occasion the researcher intends to conduct a School Action Research (PTS) as an effort to improve the principal's managerial abilities through morning briefing activities. After the morning briefing activities, there appeared to be an increase in the number of activity participants who agreed to the implementation of morning briefing activities, in addition if at the beginning of the morning breading the majority of the participants seemed still confused and awkward, then in the morning briefing activities in the sessions Furthermore, the participants of the activity seemed to be more free in expressing their ideas and thoughts in order to discuss various problems related to the condition of the school.
\end{abstract}

Keyword: Ability, Principal, Morning Briefing

\section{PENDAHULUAN}

Kepala Sekolah memiliki dua peran strategis sebagai leader dan manajer di sekolah. Ketika perencanaan pendidikan dikerjakan dan struktur organisasi persekolahannya pun disusun guna memfasilitasi perwujudan tujuan pendidikan, serta para anggota organisasi, pegawai atau karyawan dipimpin dan dimotivasi untuk mensukseskan pencapaian tujuan, tidak dijamin selamanya bahwa semua kegiatan akan berlangsung sebagaimana yang direncanakan, dan dikelola dengan baik, di antaranya adalah pengetahuan tentang manajemen. Dengan kemampuan dalam mengelola ini nantinya akan dijadikan sebagai pegangan cara berfikir, cara mengelola dan cara menganalisis sekolah dengan cara berpikir seorang manajer. Kepala sekolah harus mampu menunjukkan perilakunya dan mampu untuk mengidentifikasi dan mengembangkan jenis-jenis input sekolah; mengembangkan proses sekolah (proses belajar mengajar, pengkoordinasian, pengambilan keputusan, pemberdayaan, pemotivasian, pemantauan, pensupervisian, pengevaluasian dan pengakreditasian). 
Kepala sekolah adalah guru yang diserahi tugas tambahan untuk memimpin dan mengelola sekolah dalam upaya meningkatkan mutu pendidikan. Sebagai seorang guru, kepala sekolah sejatinya adalah juga pendidik yang harus mampu membina guru-guru di sekolahnya menjadi guru kreatif dan selalu melakukan inovasi dalam pembelajaran. Dengan adanya tugas tambahan tersebut, kepala sekolah tidak hanya dituntut untuk membina guru saja, tetapi lebih dari itu, juga dituntut untuk membina dan mengelola seluruh komponen sekolah lainnya seperti tenaga adminstrasi sekolah, tenaga perpustakaan, tenaga laboratorium dan lain sebagainya. Tuntutan-tuntutan ini adalah merupakan tugas-tugas yang baru bagi seorang guru yang diserahi tugas tambahan kepala sekolah. Di sisi lain, tujuan utama sekolah berupa peningkatan mutu pendidikan hanya dapat diraih jika seluruh komponen sekolah dapat melaksanakan tugas pokok dan fungsinya masing-masing melalui pembinaan dan pengelolaan seorang kepala sekolah yang profesional.

Karena begitu banyaknya tugastugas baru seorang kepala sekolah maka untuk menjadi seorang kepala sekolah yang profesional tentu tidaklah mudah. Diperlukan waktu yang cukup untuk belajar bagaimana melaksanakan tugastugas yang baru tersebut. Pelatihan, pembimbingan dan pembinaan bagi calon kepala sekolah merupakan upaya-upaya yang mesti dilakukan oleh pihak terkait dalam rangka melahirkan pemimpin sekolah yang berkualitas yang diharapkan mampu untuk memimpin dan mengelola sekolah dalam upaya meningkatkan mutu pendidikan.
Peraturan Menteri Pendidikan Nasional (Permendikas) Republik Indonesia nomor 28 tahun 2010 tentang penugasan guru sebagai kepala sekolah memberikan angin segar bagi peningkatan profesionalisme seorang kepala sekolah ataupun calon kepala sekolah. Dalam Permendiknas tersebut dijelaskan bahwa seorang guru yang telah dinyatakan lulus seleksi calon kepala sekolah diharuskan mengikuti pendidikan dan pelatihan sebagai kegiatan pemberian pengalaman pembelajaran teoretik maupun praktik yang bertujuan untuk menumbuhkembangkan pengetahuan, sikap dan keterampilan pada dimensidimensi kompetensi kepribadian, manajerial, kewirausahaan, supervisi, dan sosial.

SD Negeri 3 Wirotaman Kecamatan Ampelgading Kabupaten Malang sebagai sekolah tempat peneliti bertugas misalnya, memiliki 6 tenaga pendidik/guru. Pada kenyataannya, tenaga pendidik sebagai sumber daya manusia tersebut seringkali menunjukkan ketidaksolidannya dalam menghadapi berbagai permasalahan yang timbul dalam lingkup sekolah maupun di luar sekolah. Berdasarkan hasil pengamatan penulis selama mengabdi di SD Negeri 3 Wirotaman Kecamatan Ampelgading Kabupaten Malang, ditemukan beberapa permasalahan yang dihadapi warga sekolah diakibatkan oleh adanya kesalahpahaman akibat kurangnya komunikasi (miss communication). Hal inilah yang dapat menjadi salah satu penyebab kurang masilnya produktivitas kerja/kinerja tenaga pendidik dan pada akhirnya dapat mempengaruhi prestasi belajar siswa pula. 
Mempertimbangkan kondisi tersebut, maka pada kesempatan ini melalui Penelitian Tindakan Sekolah (PTS), peneliti menerapkan kegiatan morning briefing sebagai salah satu upaya untuk meningkatkan kemampuan manajerial kepala sekolah.

Berdasarkan latar belakang tersebut di atas, maka tujuan Penelitian Tindakan Sekolah (PTS) ini adalah: (1) untuk mendeskripsikan teknis pelaksanaan kegiatan morning briefing sebagai upaya untuk meningkatkan kemampuan manajerial kepala sekolah di SD Negeri 3 Wirotaman Kecamatan Ampelgading Kabupaten Malang; dan (2) untuk mengidentifikasi adanya peningkatan kemampuan manajerial kepala sekolah di SD Negeri 3 Wirotaman Kecamatan Ampelgading Kabupaten Malang setelah melakukan kegiatan morning briefing.

\section{METODE PENELITIAN}

\section{A. Metode dan Model Penelitian}

Metode penelitian yang digunakan pada penelitian ini adalah metode Penelitian Tindakan Sekolah (PTS) dengan model Kemmis dan Mc. Taggart yang merupakan model pengembangan dari model Kurt Lewin. Dikatakan demikian, karena di dalam suatu siklus terdiri atas empat komponen, keempat komponen tersebut, meliputi: (1) perencanaan, (2) aksi/tindakan, (3) observasi, dan (4) refleksi. Setelah suatu siklus selesai diimplementasikan, khususnya sesudah adanya refleksi, kemudian diikuti dengan adanya perencanaan ulang yang dilaksanakan dalam bentuk siklus tersendiri

\section{B. Perencanaan Penelitian}

Pada awal kegiatan morning briefing ini, peneliti mempersiapkan lembar kegiatan yang berupa daftar hadir, jurnal kegiatan, dan notula.

\section{HASIL DAN PEMBAHASAN}

Pelaksanan kegiatan morning briefing untuk awal kegiatan morning briefing dilaksanakan pada Semester I, yakni tanggal 4 Oktober 2018, pukul 06.30-07.00 WIB di ruang kantor dengan jumlah peserta kegiatan ada 6 orang yang terdiri dari 1 orang PNS guru dan 5 orang GTT (Guru Tidak Tetap). Dalam hal ini kepala sekolah bertindak sebagai peneliti. Adapun proses kegiatan morning briefing mengacu pada rencana kegiatan yang telah dibuat oleh kepala sekolah. Untuk pengamatan (observasi) dilaksanakan bersamaan dengan pelaksanaan kegiatan.

Pada akhir kegiatan, peserta kegiatan morning briefing diberi kesempatan untuk menuliskan kritik dan saran sehubungan dengan kegiatan yang telah dilaksanakan dengan tujuan untuk mengetahui kesan yang diperoleh peserta dalam pelaksanaan kegiatan morning briefing. Kepala sekolah mewajibkan agar seluruh peserta kegiatan mengungkapkan ide dan pikirannya secara tertulis melalui angket terbuka yang telah disiapkan oleh peneliti, tanpa menuliskan identitas apa pun pada selembar kertas yang telah disediakan.

\section{Siklus I}

Berdasarkan pengisian angket terbuka pada akhir kegiatan, maka dapat diketahui bahwa ada beberapa hal yang menjadi fokus ungkapan peserta kegiatan 
selama pelaksanaan morning briefing, diantaranya adalah sebagai berikut:

Tabel 1

Hasil Kegiatan Morning Briefing pada Awal Kegiatan Morning Briefing

\begin{tabular}{|c|c|c|}
\hline No. & Uraian Topik & $\begin{array}{c}\text { Jumlah Peserta } \\
\text { yang } \\
\text { Mengajukan } \\
\text { Pendapat }\end{array}$ \\
\hline 1. & $\begin{array}{l}\text { Ungkapan "setuju" } \\
\text { terhadap } \\
\text { pelaksanaan } \\
\text { kegiatan morning } \\
\text { briefing }\end{array}$ & 6 \\
\hline 2. & $\begin{array}{l}\text { Ungkapan "kurang } \\
\text { setuju" terhadap } \\
\text { pelaksanaan } \\
\text { kegiatan morning } \\
\text { briefing }\end{array}$ & 3 \\
\hline 3. & $\begin{array}{l}\text { Ungkapan "tidak } \\
\text { setuju" terhadap } \\
\text { pelaksanaan } \\
\text { kegiatan morning } \\
\text { briefing }\end{array}$ & - \\
\hline 4. & $\begin{array}{l}\text { Ungkapan berupa } \\
\text { kritikan }\end{array}$ & 5 \\
\hline 5. & $\begin{array}{l}\text { Ungkapan berupa } \\
\text { saran/usulan }\end{array}$ & 6 \\
\hline
\end{tabular}

Ungkapan berupa kritikan berisi tentang kekecewaan salah satu peserta kegiatan morning briefing karena kegiatan tersebut dianggap terlalu mendadak, sehingga yang bersangkutan tidak memiliki persiapan. Berdasarkan pengamatan kepala sekolah sebagai peneliti, saat awal pelaksanaan kegiatan morning briefing pada pagi itu, ada satu dua orang pendidik yang datang terlambat, lebih dari jam 06.45 WIB, hal ini mengakibatkan yang bersangkutan tidak dapat mengikuti kegiatan morning briefing dari awal.
Ungkapan berupa saran/usulan berisi tentang beberapa hal, diantaranya adalah: 1) usulan tentang waktu pelaksanaan kegiatan morning briefing, yakni sebanyak $1-2$ kali dalam satu minggu, pada pagi hari, pukul 06.30 07.00 WIB; 2) usulan tentang teknis pelaksanaan kegiatan morning briefing, diantaranya melalui pemilihan fokus pembahasan yang dijadwalkan secara tertulis, misal: setiap hari Selasa pada minggu pertama, membahas tentang permasalahan intern pendidik dan tenaga kependidikan; setiap hari Sabtu minggu pertama, membahas tentang permasalahan yang berkenaan dengan peserta didik; dan lain seterusnya, dengan bahasan yang lebih beragam dan berbeda pada tiap minggunya; 3) usulan tentang penetapan jadwal pelaksanaan morning briefing yang dikukuhkan melalui Surat Keputusan/SK Kepala Sekolah agar pelaksanaan kegiatan tersebut dapat terprogram dengan baik dan bersifat lebih resmi; 4) usulan tentang diikutsertakannya komite sekolah dalam kegiatan morning briefing; dan ada juga 5) usulan tentang pengadaan 'kotak saran' sebagai tempat bagi pihak-pihak terkait/warga sekolah untuk memberikan saran atau usulan secara tertulis, hal ini guna menghindari kurang terbukanya warga sekolah dalam mengungkapkan ide maupun pikirannya.

Dari gambaran pelaksanaan kegiatan morning briefing pada Awal kegiatan morning briefing diperoleh refleksi kegiatan sebagai berikut:

1. Kelemahan

Sebagian besar peserta kegiatan morning briefing tampak masih kebingungan dan canggung, 
hal ini mungkin dikarenakan mereka merasa bahwa kegiatan kali ini berbeda dengan kegiatan pada pertemuan-pertemuan sebelumnya. Di samping itu, dengan dilaksanakannya kegiatan morning briefing yang bersifat mendadak, tanpa pemberitahuan terlebih dahulu, serta belum terprogram dengan baik, dapat menyebabkan image negatif, baik terhadap pihak penyelenggara kegiatan maupun terhadap pelaksanaan kegiatan itu sendiri.

2. Kelebihan

Melalui kesempatan yang diberikan oleh kepala sekolah untuk menuliskan kritik dan saran sehubungan dengan kegiatan morning briefing yang telah dilaksanakan tanpa menuliskan identitas apa pun pada selembar kertas yang telah disediakan, maka peserta dapat mengungkapkan ide dan pikirannya dengan lebih bebas.

Mempertimbangkan masih terdapat banyak kekurangan/ kelemahan pada pelaksanaan kegiatan morning briefing dalam Awal kegiatan morning briefing tersebut, maka peneliti bermaksud melanjutkan kegiatan pada Awal kegiatan morning briefing.

\section{Siklus II}

Berdasarkan pengisian angket terbuka pada akhir kegiatan, maka dapat diketahui bahwa ada beberapa hal yang menjadi fokus ungkapan peserta kegiatan selama pelaksanaan morning briefing pada sesi-sesi berikutnya, diantaranya adalah sebagai berikut:

\section{Tabel 2}

\section{Hasil Kegiatan Morning briefing pada Sesi-Sesi Berikutnya}

\begin{tabular}{|c|c|c|}
\hline No. & Uraian Topik & $\begin{array}{c}\text { Jumlah Peserta } \\
\text { yang } \\
\text { Mengajukan } \\
\text { Pendapat }\end{array}$ \\
\hline 1. & $\begin{array}{l}\text { Ungkapan "setuju" } \\
\text { terhadap } \\
\text { pelaksanaan } \\
\text { kegiatan morning } \\
\text { briefing }\end{array}$ & 6 \\
\hline 2. & $\begin{array}{l}\text { Ungkapan "kurang } \\
\text { setuju" terhadap } \\
\text { pelaksanaan } \\
\text { kegiatan morning } \\
\text { briefing }\end{array}$ & - \\
\hline 3. & $\begin{array}{l}\text { Ungkapan "tidak } \\
\text { setuju" terhadap } \\
\text { pelaksanaan } \\
\text { kegiatan morning } \\
\text { briefing }\end{array}$ & - \\
\hline 4. & $\begin{array}{l}\text { Ungkapan berupa } \\
\text { kritikan }\end{array}$ & - \\
\hline 5. & $\begin{array}{l}\text { Ungkapan berupa } \\
\text { saran/usulan }\end{array}$ & 6 \\
\hline
\end{tabular}

Ungkapan berupa saran/usulan berisi tentang beberapa hal, diantaranya adalah: 1) usulan tentang waktu pelaksanaan kegiatan morning briefing yang diperpanjang pada saat hari tidak efektif, misal pada hari Sabtu kegiatan morning briefing dilaksanakan selama kurang lebih 45 menit, sehingga peserta kegiatan dalam melaksanakan morning briefing dengan lebih santai, tidak terburu-buru; 2) usulan tentang ditetapkannya kegiatan morning briefing selama 30 menit saja, karena tepat jam 7 pagi, seluruh peserta kegiatan wajib bertugas mengajar peserta didik dalam kelas masing-masing; 3) usulan tentang diadakannya kegiatan morning briefing setiap hari, dan lain sebagainya. 
Dari gambaran pelaksanaan kegiatan morning briefing pada Awal kegiatan morning briefing diperoleh refleksi kegiatan sebagai berikut:

1. Kelemahan

Masih ada peserta kegiatan yang tampak belum welcome terhadap kegiatan morning briefing yang dipimpin oleh kepala sekolah sebagai penulis, hal ini ditandai dengan kurang antusiasnya peserta kegiatan tersebut, di samping itu pasifnya peserta kegiatan tertentu pada saat pemberian saran, kritik, maupun usulan juga menjadi salah satu indikator bahwa peserta kegiatan tersebut kurang antusias dalam melaksanakan kegiatan morning briefing.

2. Kelebihan

Melalui kegiatan mengungkapkan berbagai permasalahan yang berhubungan dengan kondisi sekolah, peserta kegiatan dapat dengan bebas mengungkapkan ide dan pikirannya, tanpa takut adanya intimidasi dari pihak lain. Di samping itu, melalui model kegiatan berupa mind mapping untuk memilih alternatif pemecahan masalah, maka peserta kegiatan dapat mengemukakan pendapatnya sebagai alternatif solusi dengan leluasa, hingga pada akhirnya tanpa disadari, seluruh peserta kegiatan dapat memutuskan untuk melaksanakan suatu kegiatan guna mengatasi segala permasalahan yang ada di lingkup sekolah secara bersama-sama. Berdasarkan pengisian angket terbuka pada akhir kegiatan, dapat diketahui bahwa pada pelaksanaan
Awal kegiatan morning briefing ini, hampir seluruh peserta kegiatan menyetujui adanya kegiatan morning briefing.

\section{SIMPULAN DAN SARAN}

\section{A. Simpulan}

Secara garis besar, teknis pelaksanaan kegiatan morning briefing sebagai upaya untuk meningkatkan kemampuan manajerial kepala sekolah di SD Negeri 3 Wirotaman Kecamatan Ampelgading Kabupaten Malang adalah sebagai berikut:

1. Kepala sekolah selaku penulis merencana jadwal kegiatan morning briefing yang dilaksanakan selama 30 menit sebelum masuk ruang kelas jam pertama

2. Saat pelaksanaan kegiatan, peserta diberi stimulus untuk mengungkapkan berbagai permasalahan yang berhubungan dengan kondisi sekolah

3. Dengan bantuan guru berstatus GTT/Guru Sukwan, kepala sekolah selaku penulis, membuat model mind mapping untuk mengungkapkan ide dan pikiran peserta kegiatan sebagai alternatif solusi dari suatu permasalahan yang telah dipilih oleh peserta kegiatan secara bersama-sama

4. Pada akhir kegiatan, peserta diberi kesempatan untuk menuliskan kritik dan saran sehubungan dengan kegiatan yang telah dilaksanakan dengan tujuan untuk mengetahui kesan yang diperoleh peserta dalam pelaksanaan kegiatan morning briefing, dengan catatan tidak diperbolehkan menuliskan identitas 
apa pun pada kertas angket yang dikumpulkan

Setelah diadakannya kegiatan morning briefing, maka tampak adanya peningkatan kemampuan manajerial kepala sekolah di SD Negeri 3 Wirotaman Kecamatan Ampelgading Kabupaten Malang, hal ini ditandai dengan peningkatan jumlah peserta kegiatan yang setuju terhadap pelaksanaan kegiatan morning briefing, di samping itu jika pada pelaksanaan awal kegiatan morning briefing sebagian besar peserta kegiatan tampak masih kebingungan dan canggung, maka dalam pelaksanaan kegiatan morning briefing pada sesi-sesi berikutnya, peserta kegiatan sudah tampak lebih bebas dalam mengungkapkan ide dan pikirannya guna membahas mengenai berbagai permasalahan yang berhubungan dengan kondisi sekolah, bahkan melalui model mind mapping untuk memilih alternatif pemecahan masalah, maka peserta kegiatan dapat mengemukakan pendapatnya sebagai alternatif solusi dengan leluasa, hingga pada akhirnya tanpa disadari, seluruh peserta kegiatan dapat memutuskan untuk melaksanakan suatu kegiatan guna mengatasi segala permasalahan yang ada di lingkup sekolah secara bersama-sama

\section{B. Saran}

Mempertimbangkan hasil pembahasan tentang kegiatan morning briefing sebagai upaya untuk meningkatkan kompetensi manajerial kepala sekolah, maka ada beberapa saran yang dapat disampaikan, yakni:

1. Agar hasil kegiatan morning briefing dapat didokumentasikan secara sistematis, maka alangkah baiknya apabila kepala sekolah dengan bantuan salah satu pendidik maupun tenaga kependidikan yang ditunjuk sebagai notulis mengumpulkan ungkapan ide dan pikiran peserta kegiatan secara sistematis/tertata guna dievaluasi

2. Agar peserta kegiatan berani mengungkapkan ide dan pikirannya secara bebas sekaligus untuk menjaga privasi seluruh peserta kegiatan dari konsumsi publik yang tidak berkepentingan secara langsung dengan permasalahan yang ada, maka alangkah baiknya apabila seluruh pihak bersepakat untuk tidak mencampuradukkan permasalahan yang terjadi/dibahas pada saat kegiatan morning briefing dalam pelaksanaan kegiatan sehari-hari, terutama di lingkup sekolah

\section{DAFTAR PUSTAKA}

Arikunto, Suharsimi. 2006. Prosedur Penelitian Suatu Pendekatan Praktik. Jakarta: Asdi Mahasatya Hamalik, Oemar. 2002. Pendidikan Guru Berdasarkan Pendekatan Kompetensi. Jakarta: Bumi Aksara

Imron, Ali Burhanuddin, Maisyaroh. 2003. Manajemen Pendidikan Analisis Substantif dan Aplikasinya dalam Institusi Pendidikan. Edisi Kesatu Cetakan I. Malang: Universitas Negeri Malang

Ismuha. 2016. Kompetensi Manajerial Kepala Sekolah dalam Meningkatkan Kinerja Guru pada SD Negeri Lamklat Kecamatan 
Darussalam Kabupaten Aceh

Besar. Banda Aceh: Jurnal Administrasi Pendidikan

Pascasarjana Universitas Syiah Kuala

Lestari, T. dan Budiyono, A. 2008. Merencanakan dan

Melaksanakan Penelitian

Tindakan Sekolah. Bahan Diklat. Jakarta: Dittendik, Ditjen Mutendik Depdiknas. Jakarta:

Dittendik, Ditjen Mutendik Depdiknas

Moleong, Lexy J. 2004. Metodologi Penelitian Kualitatif. Bandung: PT. Remaja Rosdakarya

Puspitasari, Norma, M.Pd. 2015. Kemampuan Manajerial Kepala
Sekolah dalam Meningkatkan Kinerja Guru (Studi Kasus SMK Batik 1 Surakarta). Surakarta: Jurnal INFORMA Politeknik Indonesia

Rivai, Veithzal dan Murni, Sylviana. 2009. Education Management. Jakarta: PT. Raja Grafindo Persada

Sallis, Edward. 2006. Total Quality Management in Education, Manajemen Mutu Pendidikan. Yogyakarta: IRCiSoD

Sugiyono. 2010. Metode Penelitian Pendidikan, Pendekatan Kualitatif dan $R \& D$. Bandung: Alfabeta 